\title{
Identifikasi Kebutuhan Operasional CRM untuk Monitoring Tugas Akhir
}

\author{
Endah Purwanti, Badrus Zaman \\ Sistem Informasi, Faku ltas Vokasi, Universitas Airlangga \\ Kampus C Unair, J1. Mulyorejo Surabaya, Surabaya, 60115 \\ Telp : (031) 5936501, Fax : (031) 5936502 \\ endahpurwanti@fst.unair.ac.id
}

Diterima: 16 September 2016. Disetujui: 26 Oktober 2016. Dipublikasikan: Nopember 2016

\begin{abstract}
Abstrak - Customer Relationship Management (CRM) telah berkembang menjadi sebuah strategi, proses, dan teknologi untuk memperkuat hubungan perusahaan dengan pelanggannya, melalui customer life-cycle. Tren pada e-bisnis menunjukkan perubahan dari product-centric menjadi customer-centric. Universitas atau perguruan tinggi dapat mengambil keuntungan dari CRM melalui peningkatan proses student-facing. Pada penelitian ini dilakukan identifikasi kebutuhan operasional CRM untuk monitoring Tugas Akhir, dengan mengambil studi kasus di program studi D3 Sistem Informasi Fakultas Vokasi Unair. Identifikasi dilakukan dengan menggunakan model IDIC (Identify, Differentiate, Interact and Customize). Identifikasi kebutuhan merujuk pada konsumen yang ada. Aktor yang diidentifikasi sebagai konsumen sistem monitoring tugas akhir adalah mahasiswa, dosen pembimbing dan koordinator program studi. Tahap diferensiasi dilakukan pada masing-masing aktor untuk mendapatkan kepentingan dan kebutuhan terhadap informasi yang dihasilkan oleh sistem. Identifikasi kebutuhan fungsional digambarkan dalam sebuah use case diagram. Secara umum kepentingan tiap aktor adalah akses informasi secara langsung ke dalam sistem. Kemudahan dalam mendapatkan informasi akan meningkatkan kepuasan konsumen dalam mendapatkan informasi dan memutuskan strategi yang dipilih untuk memperlancar pengerjaan tugas akhir.
\end{abstract}

Kata Kunci : customer relationship management (crm), operasional crm, sistem informasi akademik, manajemen perguruan tinggi

\section{PENDAHULUAN}

Customer Relationship Management (CRM) telah berkembang selama 20 tahun terakhir ini dalam kegiatan bisnis dan korporasi. Pada awalnya CRM hanyalah sekumpulan basis data elektronik yang digunakan untuk memberikan informasi kepada konsumen. Namun saat ini CRM telah berkembang menjadi sebuah strategi, proses dan teknologi untuk memperkuat hubungan perusahaan dengan pelanggannya, melalui customer life-cycle, mulai dari kegiatan pemasaran dan penjualan, sampai dengan pelayanan purna jual[1]. Dengan sistem CRM diharapkan pelanggan mendapatkan kemudahan akses informasi, pelayanan yang me muaskan, sekaligus jaminan pelayanan purna jual yang jelas.

Tren bisnis menunjukkan perubahan dari product-centric menjadi customer-centric. Perusahaan tidak hanya semata-mata menjual produk yang bermutu dan berkualitas, namun juga menjual kepuasan pada para konsumennya. Tujuan dari CRM tidak hanya penawaran produk dan service yang berkualitas, namun lebih pada pemeliharaan dan peningkatan konsumen yang berkualitas [2]. CRM bertujuan untuk mengidentifikasi, mendapatkan, melayani dan mempertahankan konsumen yang berkualitas dengan menggunakan berbagai cara.

Perguruan tinggi adalah institusi pendidikan yang beroperasi dan berinteraksi dengan para 'konsumennya', yaitu peserta didik atau mahasiswa, baik yang aktual maupun potensial, orang tua/wali mahasiswa, dosen, peneliti, karyawan serta staff pimpinan, dewan penyantun, universitas sejenis, badan akreditasi, pemasok, organisasi bisnis dan publik, yayasan, alumni, masyarakat setempat dan media massa. Ketika CRM berkembang dalam konsep korporat, ada fenomena baru yang menunjukkan bahwa CRM mulai merambah sektor pendidikan terutama perguruan tinggi[3].

Institusi pendidikan tinggi adalah organisasi yang bersifat student-centric, yang mencakup sekelompok besar mahasiswa dengan aktivitas konselingnya, mulai dari penerimaan, pembimbingan akademik, pembimbingan karir, dan sebagainya. Perkembangan CRM dalam dunia pendidikan masih tertinggal dengan sektor korporat. Universitas atau perguruan tinggi dapat mengambil keuntungan dari CRM melalui peningkatan proses student-facing [4], personalisasi komunikasi dengan mahasiswa[5], berbagi informasi antar dosen[4], dan peningkatan kepuasan mahasiswa[6]. CRM semakin dibutuhkan oleh universitas atau perguruan tinggi untuk meningkatkan keterlibatan mahasiswa dan memberikan kesan atau pengalaman yang lebih baik 
di seluruh siklus hidup mahasiswa. Dari kenyataan tersebut, maka dalam paper ini akan dibuat analisa kebutuhan untuk operasional CRM pada perguruan tinggi. Analisa difokuskan pada sistem monitoring tugas akhir.

\section{LANDASAN TEORI}

\section{A. Customer Relationship Management (CRM)}

Menurut[7] Customer Relationship

Management (CRM) adalah sebuah strategi bisnis menyeluruh dari suatu perusahaan yang memungkinkan perusahaan tersebut secara efektif bisa mengelola hubungan dengan para pelanggan. Strategi tersebut dilakukan dengan berbagai upaya untuk menjaga pelanggan supaya tidak lari kepesaing dengan mengumpulkan segala bentuk interaksi pelanggan baik itu lewat telepon, email, masukan di situs atau hasil pembicaraan dengan staf sales and marketing.

Untuk mengimplementasikan sebuah strategi CRM, diperlukan paling tidak 3 (tiga) faktor kunci yaitu (1) orang-orang yang profesional (kualifikasi memadai), (2) proses yang didesain dengan baik dan (3) teknologi yang memadai (leading-edge technology). Tenaga yang profesional tidak saja mengerti bagaimana menghadapi pelanggan tetapi juga mengerti cara menggunakan teknologi (untuk CRM). Apapun tanpa desain yang baik akan gagal, begitu juga CRM. Perusahaan pengguna CRM harus sudah mengetahui tujuan (business objectives) dan tuntutan bisnis (business requirements) yang diinginkan dari implementasi CRM ini Kelengkapan ketiga elemen tersebut membawa dampak positif pada pelanggan sebagai sasaran tercapainya CRM. Gambar 1 menunjukkan bahwa sasaran dari CRM adalah kepuasan pelanggan[8].

Teknologi CRM paling tidak harus memiliki elemen-elemen berikut:

a. Aturan-aturan Bisnis: tergantung dari kompleksitas transaksi, aturan-aturan bisnis harus dibuat untuk memastikan bahwa transaksi dengan pelanggan dilakukan dengan efisien. Misalnya pelanggan dengan pembelian besar yang mendatangkan keuntungan besar harus dilayani oleh staf penjualan senior dan berpengalaman, dst.

b. Gudang Data (data warehouse): konsolidasi dari informasi tentang pelanggan harus dilakukan dalam satu sistem terpadu. Hasil analisa harus mampu menampilkan petunjukpetunjuk tertentu tentang pelanggan sehingga staf penjualan dan marketing mampu melakukan kampanye terfokus terhadap grup pelanggan tertentu. Nantinya gudang data ini juga harus mampu menaikkan volume penjualan dengan cross-selling atau up-selling. c. Situs (web): CRM harus memiliki kemampuan swalayan. Hanya aplikasi berbasis situs (web based) yang bisa mendukung ini. Pelanggan bis a melakukan transaksi sendiri, tahu berapa yang harus dibayar dan sebagainya.

d. Pelaporan (reporting): teknologi CRM harus mampu menghasilkan laporan yang akurat dan komprehen, nantinya berguna untuk menganalisa kelakuan pelanggan, dan lain-lain.

e. Meja Bantu (helpdesk): teknologi yang mampu mengintegrasikan informasi pelanggan ke aplikasi meja bantu akan menunjukkan ke pelanggan seberapa serius sebuah enterprise menangani pelanggannya.

Beberapa tipe CRM yaitu strategic, operational, analytical, dan collaborative CRM. Strategic CRM berfokus pada konsumen, targetnya adalah untuk memenangkan dan mempertahankan konsumen yang loyal[9]. Budaya bisnis customercentric dapat dicapai dengan menciptakan dan memberikan nilai yang lebih baik dibandingkan dengan kompetitor. Operational CRM me mfokuskan pada otomatisasi proses customer-facing seperti penjualan, marketing atau keperluan taktis. Analytical CRM memiliki fokus pada intelligent mining dari data yang berhubungan dengan konsumen untuk keperluan strategis atau taktis. Analitis CRM berfondasi pada informasi mengenai konsumen (customer-related). Collaborative CRM menjalankan teknologi di seluruh jajaran organisasi dengan tujuan untuk mengoptimalkan nilai perusahaan, partner dan konsumen. Teknologi kolaboratif meliputi penggunaan media komunikasi yang berbeda yang memungkinkan dipakai oleh konsumen, seperti email, telepon, fax dan website [10].

Supaya infrastruktur CRM lebih efektif, maka ada beberapa bagian yang harus diintegrasikan, diantaranya yaitu:

1. Integrasi Customer Content

Kemampuan untuk mengakses dan memanage semua proses yang relevan dengan customer content. Misalnya bagian customer service, mereka harus bisa mengakses semua data pelanggan, dan memahami dengan baik informasi produk perusahaannya. Mereka juga diberi fasilitas yang memadai untuk berhubungan dengan konsumen, seperti telepon, faks, aplikasi ko munikasi online, dan sebagainya.

2. Integrasi Customer Contact Information

Saat ini perusahaan semakin memperhatikan hal ini yaitu bagian dari manajemen yang menangani semua pertanyaan dari konsumen. Konsumen juga harus diberitahu bahwa perusahaan memiliki bagian yang akan menjawab semua pertanyaan dari mereka. 3. Integrasi End-to-end Business Processes

Perusahaan harus mengintegrasikan proses bisnis yang saling berhubungan. Misalnya bagian 
penjualan dan bagian customer service yang menangani aktivitas setelah penjualan. Jangan sampai kedua bagian tersebut memberikan penjelas an yang berbeda kepada konsumen.

4. Integrasi The Extended Enterprise

Rekanan perusahaan (extended enterprise) merupakan pihak yang juga mempengaruhi aktivitas perusahaan. Oleh karena itu perusahaan harus melakukan sharing informasi dengan mereka, misalnya mengenai penentuan harga atau promosi yang sedang dilaku kan.

5. Integrasi Systems

Hal-hal yang harus diintegrasikan dalam sistem diantaranya adalah legacy systems (sistem warisan), computer telephony integration, data warehousing, dan decision support technology. Tren pada CRM saat ini adalah:

a. Penggunaan Multichannel (website, telepon, email, dan sebagainya) untuk meningkatkan kepuasan pelanggan, dan menarik konsumen baru.

b. Penyediaan Call Center, sebagai pusat informasi bagi konsumen. Konsumen bisa bertanya semua hal, dan sebaliknya call center bisa menginformasikan semua informasi kepada pelanggan termasuk promosi yang sedang dilaku kan perusahaan.

c. Pembuatan Website yang memiliki fasilitas untuk mendengarkan suara konsumen, misalnya saran dan kritik.

\section{B. IDIC Model}

Salah satu framework CRM adalah IDIC yang dikembangkan oleh[11]. Menurut model IDIC, sebuah perusahaan harus melakukan empat hal untuk membuat relasi yang lebih berkualitas dengan para pelanggannya. Empat hal tersebut terdapat pada Gambar 1, yaitu Identify, Differentiate, Interact and Customize.

1. Identify, yaitu membedakan pelanggan dalam rangka untuk memahami mereka secara mendalam

2. Differentiating, tujuannya adalah untuk mengidentifikasi pelanggan potensial. Selain itu, diferensiasi dapat memungkinkan perusahaan untuk merancang dan menerapkan strategi pelanggan yang spesifik, yang dirancang untuk memenuhi kebutuhan pelanggan yang berbeda secara individual. Menurut[11], tugas diferensiasi pelanggan akan melibatkan perusahaan dalam mengkategorikan pelanggan berdasarkan kebutuhan dan nilai mereka kepada perusahaan.

3. Interacting, tujuan dari interaksi adalah mendapatkan lebih banyak informasi secara langsung dari pelanggan, sehingga dapat melayani secara tepat sesuai harapan pelanggan. Dengan demikian, perusahaan harus meningkatkan efektivitas interaksi mereka dengan klien. Interaksi pelanggan yang efektif memberikan wawasan yang lebih baik terhadap kebutuhan pelanggan.

4. Customizing, menyesuaikan penawaran dan komunikasi secara personal untuk memastikan bahwa harapan pelanggan terpenuhi. Memang, perusahaan harus mengadaptasi beberapa aspek perilaku terhadap pelanggan, berdasarkan kebutuhan dan nilai individu.

Gambar 2 menunjukkan bahwa kegiatan identifikasi dan interaksi pada framework IDIC, sebenarnya berada pada fase operasional CRM. sedangkan kegiatan diferensiasi dan kastemisasi merupakan fase analytical CRM.

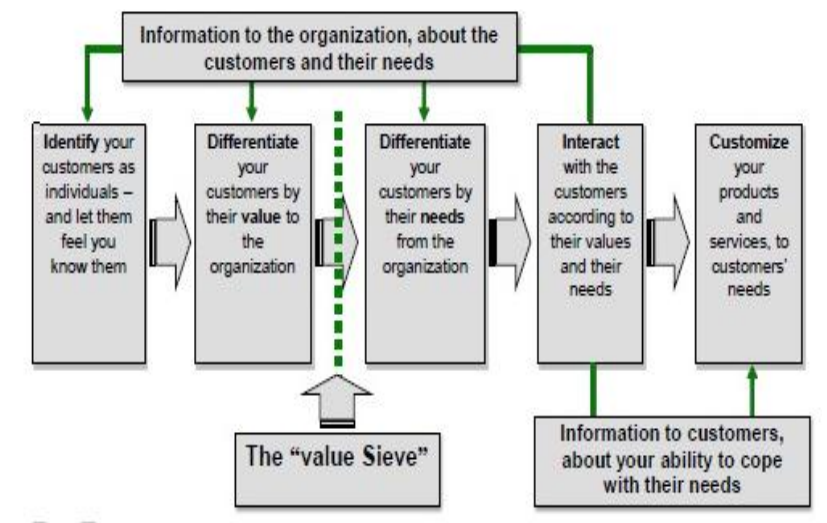

Gambar 1. IDIC Framework

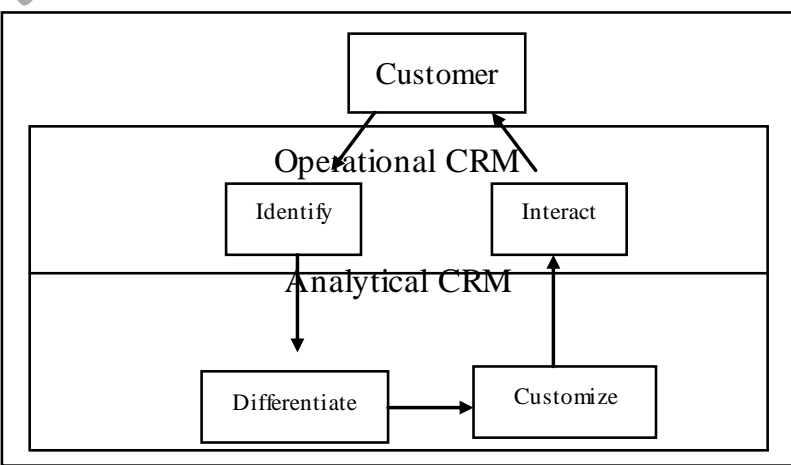

Gambar 2. Model IDIC

\section{IMPLEMENTASI MODEL}

\section{A. Identifikasi Sistem Akademik Perguruan Tinggi}

Kata akademik berasal dari Bahasa Inggris, yaitu academy. Secara harfiah, kata akade mik berarti sekolah, yang juga dapat diartikan sebagai segala sesuatu yang berhubungan dengan proses penunjang kegiatan sekolah atau lembaga pendidikan beserta pelaku didalamnya. Berdasarkan pengertian akademik tersebut, maka sistem informasi akademik dapat diartikan sebagai segala macam hasil interaksi antar elemen di lingkungan akademik untuk menghasilkan informasi yang kemudian dijadikan 
landasan pengambilan keputusan, melaksanakan tindakan, baik oleh pelaku proses itu sendiri maupun dari pihak luar.

Kegiatan akademik perguruan tinggi yang utama adalah proses belajar mengajar (PBM) di kelas yang diampuh oleh seorang dosen dan diikuti oleh sekelompok mahasiswa. Tugas akhir adalah sebuah mata kuliah yang harus ditempuh oleh mahas is wa men jelang akhir studinya, berupa laporan pelaksanaan suatu penelitian untuk memecahkan suatu masalah dengan menggunakan kaidah-kaidah tertentu. Mata kuliah ini biasanya berbentuk proyek yang dikerjakan secara mandiri oleh mahasiswa dengan dibimbing oleh seorang dosen pembimbing. Karena metode pengerjaan secara mandiri tersebut, maka permasalahan yang sering muncul adalah kesulitan dosen pembimbing dalam memantau kemajuan mahasis wa bimbingannya.

Prosedur yang harus dilakukan adalah pertama mahasiswa menemukan topik permasalahan yang akan diselesaikan, kemudian mahasiswa membuat proposal tugas akhir dan berkonsultasi dengan dosen pembimbing untuk mempersiapkan sidang proposal. Setelah proposal dinyatakan layak untuk dikerjakan, maka mahasiswa masuk dalam masa penyelesaian tugas akhir. Untuk dapat mengajukan sidang tugas akhir, mahasiswa harus memenuhi jumlah minimal bimbingan yang harus dilakukan dengan dosen pembimbing sebagai salah satu syarat ujian.

\section{B. Identifikasi Kebutuhan Sistem Monitoring Tugas Akhir}

Untuk melakukan identifikasi kebutuhan sistem monitoring tugas akhir, dilakukan observasi dan pengumpulan data pada institusi asal penulis, yaitu Universitas Airlangga (Unair), terutama pada Program Studi D3 Sistem Informasi, Fakultas Vokasi.

Tugas akhir pada prodi ini disebut dengan Proyek Sistem Informasi (PSI). Dari identifikasi sistem akademik perguruan tinggi pada bagian sebelumnya maka dapat disimpulkan bahwa konsumen sistem ini adalah seperti terlihat pada Tabel 1. Kebutuhan fungsional sistem tergambar pada use case pada Gambar 3. Use case ini hanya menggambarkan fungsi-fungsi yang berhubungan dengan konsep CRM saja, fungsi sistem informasi akademik sendiri tidak terga mbar $d$ isini.

TABEL 1. IDENTIFIKASI DAN DIFERENSIASI AKTOR KEGIATAN AKADEMIK

\begin{tabular}{|l|l|l|}
\hline No. & Identifikasi Pelaku & \multicolumn{1}{|c|}{ Dife rensiasi Ke pentingan } \\
\hline 1. & Mahasiswa & $\begin{array}{l}\text { Pelaku pengerjaan tugas akhir. } \\
\text { Dokumentasi pertemuan } \\
\text { dengan dosen pembimbing. }\end{array}$ \\
\hline 2. & $\begin{array}{l}\text { Dosen sebagai } \\
\text { pembimbing Tugas } \\
\text { Akhir }\end{array}$ & $\begin{array}{l}\text { Memantau } \\
\text { pengerjaan tugas akhir oleh } \\
\text { anak bimbingan. }\end{array}$ \\
\hline
\end{tabular}

\begin{tabular}{|c|c|c|}
\hline No. & Identifikasi Pelaku & Dife rensiasi Ke pentingan \\
\hline & & $\begin{array}{ll}\text { Dokumentasi } & \text { pelaksanaan } \\
\text { pembimbingan }\end{array}$ \\
\hline 3. & $\begin{array}{ll}\begin{array}{l}\text { Koordinat or } \\
\text { Prorgam }\end{array} \\
\text { (KPS) }\end{array}$ & $\begin{array}{lr}\text { Kemudahan } & \text { mendapatkan } \\
\text { informasi } & \text { kemajuan } \\
\text { penyelesaian tugas akhir }\end{array}$ \\
\hline 4. & Bagian Tata Usaha & $\begin{array}{l}\text { Sebagai operator dan penyedia } \\
\text { data utama }\end{array}$ \\
\hline
\end{tabular}

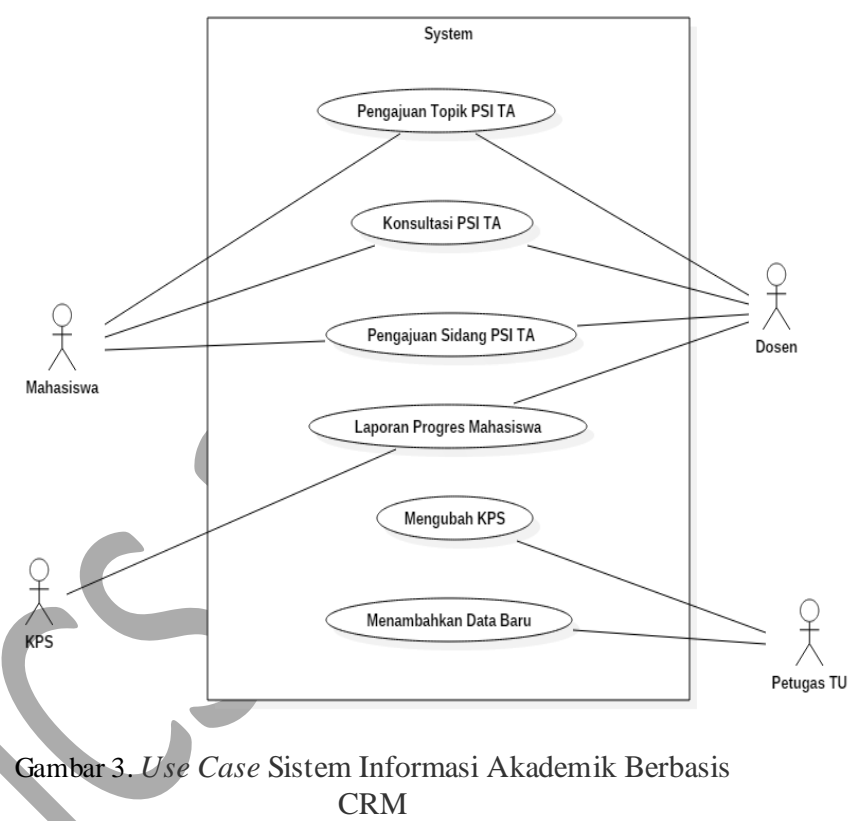

Berikut ini penjelasan dari use case yang ada:

1. Use case pengajuan topik PSI/TA, digunakan untuk mengajukan topik tugas akhir yang akan dikerjakan

2. Use case konsultasi PSI/TA, oleh mahasiswa dan dosen pembimbing, merupakan proses untuk merekam akt ifitas pembimbingan

3. Use case pengajuan sidang PSI/TA, merupakan proses untuk mengajukan tugas akhir

4. Use case laporan progres mahasiswa, melihat progress pengerjaan tugas akhir.

5. Use case cetak mengubah KPS, merupakan proses edit KPS

Use case menambah data baru. Fitur ini digunakan untuk data base yang ada.

\section{KESIMPULAN}

Identifikasi kebutuhan fungsional sistem informasi monitoring tugas akhir dilakukan dengan menggunakan model IDIC (Identify, Differentiate, Interact and Customize). Fungsi-fungsi yang berhasil diidentifikasi diharapkan dapat menambah kepuasan konsumen perguruan tinggi dalam mendapatkan informasi. Informasi diberikan sesuai dengan tingkat kepentingan masing-masing konsumen. 


\section{REFERENSI}

[1] Winer, R. 2001., A Framework for Customer Relationship Management, California Management Review, 43(4), 89105.

[2] Kotler, P., dan Fox, 1995, K. Strategic Marketing for Educational Institutions, Englewood Cliffs, N.J.: Prentice Hall.

[3] Grant, G., dan Anderson, G. , 2002, Web Portals and Higher Education, Willey Company, USA.

[4] Chen, J., and Ching, R. K. H., 2005, An Examination of the Effects of CRM Practices on CRM Effectiveness and Business Performance, Proceedings of the Eleventh Americas Conference on Information Systems, August 1114, Omaha, NE, USA, 179-188.

[5] Karimi, J., Somers, T., and Gupta, Y., 2001, Impact of Information Technology Management Practices on Customer Service, Journal of Management Information Systems, 17(4), 125-158.

[6] Bradshaw, I., and Brash, C., 2001, Management Customer Relationships in the e-Business World, International Journal of Retail and Distribution Management, 29(12) $520-530$.
[7] Kalakota, R., dan Robinson, M, 2001, e-business 2.0: Roadmap for Success, Addison Willey.

[8] Fatima Zohra Ennaji; Abdelaziz El Fazziki; Mohamed Sadgal; Djamal Benslimane, 2015. Social intelligence framework: Extracting and analyzing opinions for social CRM. IEEE/ACS 12th International Conference of Computer Systems and Applications (AICCSA), Pages: 1-

[9] Miguel Rodel Felipe; Khin Mi Mi Aung; Xia Ye; Wen Yonggang, 2015. StealthyCRM: A Secure Cloud CRM System Application that Supports Fully Homomorphic Database Encryption. International Conference on Cloud Computing Research and Innovation (ICCCRI), Pages: 97 -105 .

[10] S. S. Askool; K. Nakata, 2010. Scoping study to identify factors influencing the acceptance of social CRM, IEEE International Conference on Management of Innovation \& Technology, Pages: $1055-1060$.

[11] Peppers, D. \& Rogers, M., 2004. Managing Customer Relationships: A Strategic Framework. Hoboken, New Jersey: John Wiley \& Sons. 